\title{
Mask Protection Against Lead Exposure and Its Correlation with Erythropoiesis in Automotive Body Painters at Ligu District, Semarang, Indonesia
}

\author{
Budi Santosa', Ali Rosidi ${ }^{2}$, Herlisa Anggraini ${ }^{3}$, Zahra Maharani Latrobdiba ${ }^{2}$, Fitriani Nur Damayanti ${ }^{4}$, \\ Heru Santoso Wahito Nugroho $\mathbb{1}^{5}$ \\ 'Department of Medical Laboratory Science, Universitas Muhammadiyah Semarang, Semarang, Indonesia; ${ }^{2}$ Department of Nutrition, Faculty of \\ Nursing and Health Science, Universitas Muhammadiyah Semarang, Semarang, Indonesia; ${ }^{3}$ Department of Medical Laboratory Technology, Faculty of \\ Nursing and Health Science, Universitas Muhammadiyah Semarang, Semarang, Indonesia; ${ }^{4}$ Department of Midwifery, Faculty of Nursing and Health \\ Science, Universitas Muhammadiyah Semarang, Semarang, Indonesia; ${ }^{5}$ Department of Health, Poltekkes Kemenkes Surabaya, Surabaya, Indonesia
}

Correspondence: Budi Santosa, Department of Medical Laboratory Science, Universitas Muhammadiyah Semarang, Jl. Kedungmundu Raya I8, Semarang, 50273, Central Java, Indonesia Email budisantosa@unimus.ac.id

Introduction: Automotive body painters are at risk of excessive lead exposure that may compromise their health. This study examined the protective effects of masks against lead exposure and its correlation with blood profile of automotive body painters at Ligu district, Semarang, Indonesia.

Material and Methods: This cross-sectional study included 61 painters at Ligu district, Semarang, Indonesia (mean age 45 years, $100 \%$ male). Mask use was categorized into "frequent" and "infrequent". Blood samples were taken to measure lead exposure and haematological parameters (haemoglobin/HGB, erythrocytes/RBC, haematocrit/HCT, mean corpuscular haemoglobin/MCH, mean corpuscular volume/MCV, mean corpuscular haemoglobin concentration/MCHC). Effectivity of mask use against lead exposure was analysed with Fisher's exact test, while lead exposure and haematopoietic parameters were evaluated with Pearson's correlation tests. Results: There were 26 automotive painters (42.6\%) classified as unfrequent mask users, and all of them had high blood lead levels. Most haematopoiesis parameters were in normal range. Workers with infrequent mask use were 1.269 more likely to be exposed to lead compared to those with frequent mask use (CI 95\%, 1.082-1.552). Significant associations were found between lead exposure and RBC $(p=0.0, r=-0.53)$, HGB $(p=0, r=-0.61)$, and HCT $(p=0.00, r=-0.61)$. No significant correlations were observed between lead exposure and $\mathrm{MCV}, \mathrm{MCH}, \mathrm{MCHC}$.

Conclusion: Lead exposure was significantly associated with haematological parameters RBC, HGB, and HCT, confirming the effects of prolonged exposure on blood profile. However, mask use provided significant protection against lead exposure in automotive body painters and should be an obligatory gear for workers.

Keywords: mask, lead, haematopoiesis, automotive painters

\section{Introduction}

Lead is a common material found in various industries. Automotive painting, for instance, uses lead to improve paint quality in terms of brightness, solubility, and drying time. ${ }^{1}$ As a highly toxic non-essential metal, lead comes with a number of environmental risks and health hazards. ${ }^{2-6}$ Regular exposure to lead may cause anaemia, kidney and liver damage. $^{7,8}$

The impact of lead exposure depends on the route, duration, and dose. Lead can enter the human body through ingestion, absorption, and most predominantly, inhalation (80\%). ${ }^{9}$ Approximately half of lead exposure in children is obtained through ingestion, while it contributes to only $10-15 \%$ in adults due to more advanced hygiene practices. ${ }^{10-12}$

Car painters are exposed to lead during the entire painting process, starting from sanding, priming with epoxy, mixing paint with thinner, paint spraying until finishing with varnish. Lead may enter the body through inhalation, absorption 
through the skin, or ingestion by unhygienic hand-to-mouth transmissions. Lead is mostly absorbed through skin after 12 hours of constant exposure. ${ }^{13}$

In the body, lead is metabolized and circulated in blood, tissues, and bones. As a result, biomarkers for lead exposure include blood, soft tissues, bones, hair, urine, sweat, teeth, nails, and bile. ${ }^{14}$ The majority $(95 \%)$ of absorbed lead is carried by the erythrocytes, making it the best marker to measure lead exposure. ${ }^{2}$ Lead interferes with erythropoietin, a hormone that promotes erythropoiesis, thus causing hampered erythrocyte production. ${ }^{15}$ Lead also inhibits deltaaminolevulinate dehydratase (ALAD) enzyme which is involved in the formation of heme, consequently reducing haemoglobin levels and altering erythrocyte volume as seen from decreased haematocrit levels. Those changes can be observed from erythrocyte indices, particularly mean corpuscular haemoglobin $(\mathrm{MCH})$, mean corpuscular volume (MCV), and mean corpuscular haemoglobin concentration (MCHC). Erythrocyte indices are useful to identify anaemia. ${ }^{16-18}$

For automotive body painters, mask usage may play a big role in the amount of lead exposure. Masks serve as a protective item against lead inhalation, but its use vary between individuals from regular, occasional, to never. The objective of this study is to examine the degree of protection from wearing masks against lead exposure and its correlation with haematopoietic systems in automotive body painters in Ligu district, Semarang, Indonesia. Ligu district is in the northern area of Semarang which is a heavily populated with automotive body painting as the main home industry of the region.

\section{Materials and Methods Design and Subjects}

In this cross-sectional study, data was collected in automotive body painting workshops at Ligu district, Semarang, from December 2020 to March 2021. Subjects were randomly chosen according to the following inclusion criteria: (i) provided written consent, (ii) currently works as an auto body painter in workshops at Ligu district, Semarang. Exclusion criteria were (i) has worked in the workshop for less than 5 years (because they might get lead exposure from other places), (ii) has working hours less than 8 hours in total daily work load, and (iii) is consuming multivitamin supplements. Based on the inclusion and exclusion criteria, then 61 research subjects were obtained.

\section{Ethical Consideration}

As a scientific study involving humans, this study received ethical approval prior to data collection. In order to avoid conflicts of interest, ethical approval was obtained from the Health research ethics committee from other university, namely the Health Research Ethics Committee, Faculty of Medicine, Universitas Sultan Agung Semarang, with the number: 183/VII/2121/Komisi Bioetik. The ethical approval was given based on the results of an evaluation conducted by the ethics examiner team, which showed that this study had applied ethical principles of medical and health research, especially the Declaration of Helsinki which upholds autonomy, does not harm, maintains justice and benefits for the participants, such as: counseling based on the results of related laboratory examinations. All participants also agreed to be involved as research subjects by signing an informed consent, having previously been clearly informed about the purpose and procedures of this study.

\section{Measurements}

\section{General Characteristics of Subjects}

The general characteristics of subjects (age, sex, work period, working hours/day, room ventilation, exercise habit) were obtained using a questionnaire.

\section{Mask Use}

Mask use of automotive body painters at workshops in Ligu district were observed daily for a week. Afterwards, subjects were interviewed about their average mask use during work: always, sometimes, or never. The result from the interview is later categorized as "frequent" and "infrequent" (for workers who sometimes or never wear masks). Observations and interviews were conducted simultaneously as a cross check. This was done in order to minimize bias in data collection. 


\section{Lead Levels, Haemoglobin (HGB), Erythrocytes/Red Blood Cell (RBC), Haematocrit (HCT), MCV, MCH, $\mathrm{MCHC}$}

Blood samples were taken from the superficial veins of antecubital fossa and then stored in purple evacuated tubes (with K2EDTA). The samples were stored in a plastic transport box and sent to the BioMedical Laboratory Universitas Muhammadiyah Semarang for analysis using a haematology analyzer by photometry and electrical impedance. The results of laboratory tests were based on the following normal limits: Lead levels $(<40 \mu \mathrm{g} / \mathrm{dL})$, HGB $(13.3-16.7 \mathrm{~g} / \mathrm{dL})$, RBC (4.5-5.7 x 10 $12 / \mathrm{L})$, HCT (35-53\%), MCV (77-98 fL), MCH (26-33 pg), MCHC (33-37 g/dL). The measurement of blood lead was done at GAKI Laboratory Universitas Diponegoro using atomic absorption spectrophotometer (AAS).

\section{Other Data}

Additional data that were collected consisted of age, gender, work period, working hours/day, ventilation, and exercise habits. Ventilation was measured based on room area and window width which should be around 10-25\%. Exercise habits were categorized as "active" when done twice a week and "not active" when only done once or not at all in a week.

\section{Statistical Analysis}

Categorical variables (age, gender, work period, working hours/day, ventilation, exercise habits) were described in numbers and percentage. The degree of protection from masks were analysed using Fisher's exact test, while the association between lead exposure and haematopoietic system were evaluated with Pearson's correlation tests.

\section{Results}

The characteristics of subjects are presented in Table 1. Long-term work period ( $>5$ years) and long working hours $(>8$ hours) were specifically used as an inclusion and exclusion criteria to determine subjects. The 61 subjects were chosen as they fulfilled the inclusion criteria while the remaining four were excluded. We found that subjects with infrequent mask use had higher blood lead levels $(100 \%, \mathrm{n}=26)$ than those with frequent mask use (Table 2$)$. In this case, the limit for high blood lead levels is 40 micrograms per deciliter. ${ }^{19}$ The risk of lead exposure was 1.296 times higher for infrequent mask users in comparison to frequent users $(\mathrm{p}=0.016)$.

Table I Characteristics of Subjects

\begin{tabular}{|l|l|}
\hline Mean Age (Years) & $\mathbf{4 4 . 2 3 \pm 1 0 . 3 3}$ \\
\hline $\begin{array}{l}\text { Gender } \\
\text { Female }\end{array}$ & $61(100 \%)$ \\
\hline Work period & $0 \%)$ \\
$\leq 5$ years & \\
$>5$ years & $4(6.2 \%)$ \\
\hline Working hours/day & $61(93.8 \%)$ \\
$\leq 8$ hours & $4(6.2 \%)$ \\
$>8$ hours & $61(93.4 \%)$ \\
\hline Room ventilation & \\
Inadequate & $44(72.1 \%)$ \\
Adequate & $17(27.9 \%)$ \\
\hline Exercise habit & \\
Not active & $37(60.7 \%)$ \\
Active & $24(39.3 \%)$ \\
\hline
\end{tabular}


Table 2 Relation of Blood Lead Concentrations and Mask Use in Automotive Body Painters

\begin{tabular}{|c|c|c|c|c|c|c|c|c|c|}
\hline \multirow[t]{3}{*}{ Mask Use } & \multicolumn{4}{|c|}{ Blood Lead Levels } & \multirow{2}{*}{\multicolumn{2}{|c|}{ Total }} & \multirow[t]{3}{*}{$p$} & \multirow[t]{3}{*}{$\mathbf{R R}$} & \multirow[t]{3}{*}{$95 \% \mathrm{Cl}$} \\
\hline & \multicolumn{2}{|c|}{ Normal $(<40 \mu g / d L)$} & \multicolumn{2}{|c|}{ High $(\geq 40 \mu g / d L)$} & & & & & \\
\hline & $\mathbf{n}$ & $\%$ & $\mathbf{n}$ & $\%$ & $\mathbf{n}$ & $\%$ & & & \\
\hline Infrequent & 0 & 0 & 26 & 100 & 26 & 100 & 0.016 & 1.296 & $1.082-1.552$ \\
\hline Frequent & 8 & 22.9 & 27 & 77.1 & 35 & 100 & & & \\
\hline
\end{tabular}

Most haematological parameters for all subjects were still within normal range, including MCHC (Table 3). Average blood lead levels were above normal values although it was still generally acceptable (Table 4). This refers to Decharat et al that the blood lead level that can still be tolerated is $<60$ micrograms per deciliter. ${ }^{19}$

Blood lead levels were significantly and strongly correlated with HGB, RBC, and HCT $(-0.61,-0.53,-0.61)$, suggesting that higher lead exposure caused decreased levels of HGB, RBC, and HCT. On the contrary, no significant correlation was observed between blood lead levels and $\mathrm{MCV}, \mathrm{MCH}$, and $\mathrm{MCHC}$.

\section{Discussion}

Results from this study affirmed that mask use largely affected the extent of lead exposure. Automotive body painters at Ligu district Semarang with infrequent mask use were 1.296 times more likely to be exposed to lead compared to those

Table 3 Haematological Parameters of Automotive Body Painters in Ligu District, Semarang, Indonesia

\begin{tabular}{|l|c|c|c|c|}
\hline \multirow{2}{*}{ Parameters } & \multicolumn{3}{|c|}{} & \multirow{2}{*}{ Normal Limit } \\
\cline { 2 - 4 } & Low & Normal & High & \\
\hline HGB & $5(8.2 \%)$ & $53(86.9 \%)$ & $3(4.9 \%)$ & $13.3-16.7 \mathrm{~g} / \mathrm{dL}$ \\
\hline RBC & $20(32.8 \%)$ & $30(49.2 \%)$ & $11(18.0)$ & $4.5-5.7 \times 10^{12} / \mathrm{L}$ \\
\hline HCT & $18(29.5 \%)$ & $43(70.5 \%)$ & $0(0 \%)$ & $35-53 \%$ \\
\hline MCV & $14(23 \%)$ & $41(67.2 \%)$ & $6(9.8 \%)$ & $77-98 \mathrm{fL}$ \\
\hline $\mathrm{MCH}$ & $19(31.1 \%)$ & $34(55.7 \%)$ & $8(13.1) \%$ & $26-33 \mathrm{Pg}$ \\
\hline $\mathrm{MCHC}$ & $0(0 \%)$ & $61(100 \%)$ & $0(0 \%)$ & $33-37 \mathrm{pg} / \mathrm{dL}$ \\
\hline
\end{tabular}

Table 4 Relation of Haematological Parameters with Blood Lead Levels

\begin{tabular}{|l|l|l|l|l|l|l|l|}
\hline & Normal Limit & Average & \multicolumn{1}{|c}{ Max } & \multicolumn{2}{c|}{ Min } & & \multicolumn{2}{c|}{ Analysis } \\
\cline { 4 - 8 } & & & & & Correlation & $p$ & \\
\hline Blood $\mathrm{Pb}$ & $<40 \mu \mathrm{g} / \mathrm{dL}$ & $42.99 \pm 4.53$ & 52.3 & 27.4 & & & \\
\hline $\mathrm{HGB}$ & $13.3-16.7 \mathrm{~g} / \mathrm{dL}$ & $14.01 \pm 1.33$ & 16.1 & 11.3 & Lead-HGB & 0.00 & -0.61 \\
\hline $\mathrm{RBC}$ & $4.5-5.7 \times 10^{12} / \mathrm{L}$ & $4.94 \pm 0.6 \mathrm{I}$ & 5.98 & 3.99 & Lead-RBC & 0.00 & -0.53 \\
\hline $\mathrm{HCT}$ & $35-53 \%$ & $42.14 \pm 4.1 \mathrm{I}$ & 48.6 & 34 & Lead-HCT & 0.00 & -0.61 \\
\hline $\mathrm{MCV}$ & $77-98 \mathrm{fL}$ & $28.53 \pm 2.42$ & 33.3 & 22.7 & Lead-MCV & 0.63 & 0.06 \\
\hline $\mathrm{MCH}$ & $26-33 \mathrm{pg}$ & $85.77 \pm 7.28$ & 100.90 & 68.4 & Lead-MCH & 0.58 & 0.01 \\
\hline $\mathrm{MCHC}$ & $33-37 \mathrm{pg} / \mathrm{dL}$ & $33.25 \pm 0.39$ & 35.9 & 32.5 & Lead-MCHC & 0.46 & 0.09 \\
\hline
\end{tabular}


who frequently wore masks. This study also found a significant difference $(p=0.016)$ between employees with frequent mask use and employees with infrequent use against lead exposure, further proving the importance of masks as a protective gear against pollutants including lead that can be absorbed through inhalation. Kuruvilla et al also reported that the use of activated carbon fabric (ASF) masks that successfully reduced lead exposure. ${ }^{20}$

Our study had several limitations, particularly the type of masks. There is a wide variety of mask types, including disposable face masks, bandana masks, pre-shaped face masks, and full-face respirators. ${ }^{21,22}$ Each type provides different levels of protection against airborne contaminants, thus longitudinal studies with specified type of masks are required. The findings in this study are independent of our previous work where mask use had no significant correlation with cognitive deficits from lead exposure. Cognitive decline is considerably harder to measure as detectable signs may only appear after a long period of time even though lead exposure may exceed the tolerable level at present. ${ }^{23}$

We found a strong negative correlation between blood lead concentrations with HGB, RBC, HCT. Inhalation is a major exposure route for lead since more than $40 \%$ of lead is absorbed into the respiratory system before getting distributed in blood. Approximately $95 \%$ of lead is attached to red blood cells and the rest is dissolved in plasma. Some lead is stored in tissues and bones while the excretion is primarily through kidney and digestive system. ${ }^{24}$ Lead has been proven to disrupt heme synthesis and shorten the lifespan of erythrocytes, consequently decreasing HGB, RBC, and HCT concentrations. Lead interferes with the enzymatic activity in the beginning, middle, and end of heme biosynthesis. At the initial steps, lead inhibits $\delta A L A D$ enzyme, an enzyme that triggers heme biosynthesis. ${ }^{25}$ As a result, the transformation of $\delta A L A$ into porphobilinogen (PBG) is blocked ${ }^{26}$ and the concentration of $\delta A L A$ is increased in blood and urine. Lead also hinders coproporphyrinogen oxidase in the midway process of heme synthesis, leading to elevated coproporphyrinogen levels. The last enzyme affected by lead is ferrochelatase ${ }^{27}$ which resulted in increased protoporphyrin concentration in red blood cells or known as free erythrocyte protoporphyrin. ${ }^{28}$ In addition, lead has pro-oxidant activity that may incite oxidative stress in vulnerable erythrocyte membranes, thus reducing erythrocytes lifespan and eventually causing hemolytic anaemia. ${ }^{27,29}$

No significant association was found between lead exposure with $\mathrm{MCV}, \mathrm{MCH}$, and $\mathrm{MCHC}$. Blood lead levels in automotive body painters were generally high but still within tolerable range ( $40 \mu \mathrm{g} / \mathrm{dl}-60 \mu \mathrm{g} / \mathrm{dl})$. Value threshold for blood lead range $40 \mathrm{~g} / \mathrm{dL}$. Similarly, all haematological parameters were also within normal range. Erythrocyte indices ( $\mathrm{MCV}, \mathrm{MCH}, \mathrm{MCHC}$ ) can be calculated from $\mathrm{HGB}, \mathrm{RBC}$, and HCT. The calculation of erythrocyte indices revealed the mean volume of erythrocytes and mean haemoglobin concentration per erythrocyte. Clinically, erythrocyte indices are used to diagnose and identify anaemia.

The results of this study are expected to provide justification that the use of masks as personal protective equipment for automotive painters is very important, because it has been proven to have an effect on lead levels in the blood which in turn can have an impact on HGB, RBC, HCT levels. Indeed, there were also changes in MCV, MCH, and MCHC levels; but still within a tolerable level. Logically, if the concentration of lead exposure studied was higher, it is possible that changes in $\mathrm{MCV}, \mathrm{MCH}$, and $\mathrm{MCHC}$ levels would exceed tolerable limits. Of course, to prove this, further research is needed involving automotive paint workers with a high duration and frequency of work or who are too ignorant to use masks as personal protective equipment.

\section{Conclusion}

In conclusion, the results of this study showed that automotive body painters who occasionally or never wear masks while working had higher risks for lead exposure than workers who always wear masks. We also affirmed that lead exposure significantly affected blood profile, particularly HGB, RBC, and HCT. Further longitudinal studies with specified mask types are required to be able to make recommendations of protective gears for automotive body painters.

\section{Acknowledgments}

We thank all subjects who have participated in our study, our colleagues at the laboratory who provided great help in blood analysis, and Universitas Muhammadiyah Semarang for the full support. 


\section{Disclosure}

The authors declare no potential conflict of interest regarding the study and the publication of this paper.

\section{References}

1. Gottesfeld P. Time to ban lead in industrial paints and coatings. Front Public Health. 2015;3:144. doi:10.3389/fpubh.2015.00144

2. Wani AL, Ara A, Usmani JA. Lead toxicity: a review. Interdiscip Toxicol. 2015;8(2):55-64. doi:10.1515/intox-2015-0009

3. Halmo L, Nappe TM. Lead toxicity. In: StatPearls. Treasure Island (FL): StatPearls Publishing; 2021:1-25.

4. Gidlow DA. Lead toxicity. Occup Med. 2015;65(5):348-356. doi:10.1093/occmed/kqv018

5. Rajkumar V, Gupta V. Heavy metal toxicity. In: StatPearls. Treasure Island (FL): StatPearls Publishing; 2020:1-33.

6. Gump BB, Hruska B, Parsons PJ, et al. Dietary contributions to increased background lead, mercury, and cadmium in 9-11 year old children: accounting for racial differences. Env Res. 2020;185:109308. doi:10.1016/j.envres.2020.109308

7. Santosa B, Iswara A, Ernanto AR. IR-bagendit leaves water extract as preventing agent in hematopoiesis, degeneration and necrosis in kidney tubules of lead-exposed rats. Pakistan J Med Health Sci. 2019;13(3):899-904.

8. Kwon S, Bae O, Noh J, et al. Erythrophagocytosis of lead-exposed erythrocytes by renal tubular cells: possible role in lead-induced nephrotoxicity. Environ Health Perspect. 2015;(2):120-127. doi:10.1289/ehp.1408094

9. Kastury F, Smith E, Lombi E, Donnelley MW, Cmielewski PL, Parsons DW. Dynamics of lead bioavailability and speciation in indoor dust and X-ray spectroscopic investigation of the link between ingestion and inhalation pathways. Env Sci Technol. 2019;53(19):11486-11495. doi:10.1021/ acs.est.9b03249

10. Assi MA, Noor M, Hezmee M, Haron AW, Yusof M, Sabri M. The detrimental effects of lead on human and animal health. Vet World. 2016;9:2231-2916. doi:10.14202/vetworld.2016.660-671

11. Kumar A, Kumar A, Chaturvedi AK. Lead toxicity: health hazards, influence on food chain, and sustainable remediation approaches. Int $J$ Environ Res Public Health. 2020;17:1-33. doi:10.3390/ijerph17072179

12. Leonas R, Noor Z, Rasyid HN, Madjid TH, Tanjung F. Effect of lead nanoparticles inhalation on bone calcium sensing receptor, hydroxyapatite crystal and receptor activator of nuclear factor-kappa B in rats. Acta Inf Med. 2016;24(5):343-346. doi:10.5455/aim.2016.24.343-346

13. Kim H, Jang T, Chae H, et al. Evaluation and management of lead exposure. Ann Occup Environ Med. 2015;27(1):1-9. doi:10.1186/s40557-0150085-9

14. Charkiewicz AE, Backstrand JR. Lead toxicity and pollution in Poland. Int J Environ Res Public Health. 2020;17(12):1-14. doi:10.3390/ ijerph17124385

15. Bunn HF. Erythropoietin. Cold Spring Harb Perspect Med. 2013;3:a011619. doi:10.1101/cshperspect.a011619

16. Hsieh NH, Chung SH, Chen SC, et al. Anemia risk in relation to lead exposure in lead-related manufacturing. BMC Public Health. 2017;17 (1):1-12. doi:10.1186/s12889-017-4315-7

17. Kalahasthi R, Barman T. Effect of lead exposure on the status of reticulocyte count indices among workers from lead battery manufacturing plant. Toxicol Res. 2016;32(4):281-287. doi:10.5487/TR.2016.32.4.281

18. Santosa B, Anggraini H, Dyah I, Muliatun N, Nugroho A. Erythrocyte index of residents exposed to lead in Tambaklorok, Semarang, Indonesia. $J$ Teknol Lab. 2020;9(2):151-158. doi:10.29238/teknolabjournal.v9i2.213

19. Decharat S, Kongtip P, Thampoophasiam P, Thetkathuek A. An examination of blood lead levels in Thai Nielloware workers. Saf Health Work. 2012;3(3):216-223. doi:10.5491/SHAW.2012.3.3.216

20. Kuruvilla A, Pillay VV, Adhikari P, et al. Role of activated carbon fabric mask to prevent lead absorption-a short report. Toxicol Ind Health. 2008;24(9):569-572. doi:10.1177/0748233708100367

21. Bowen LE. Does that face mask really protect you? Appl Biosaf. 2010;15(2):67-71. doi:10.1177/153567601001500204

22. Gutierrez AM, Galang MD, Seva RR, Lu MC, Ty DRS. Designing an improved respirator for automotive painters. Int J Ind Ergon. 2014;44 (1):131-139. doi:10.1016/j.ergon.2013.11.004

23. Laksmidewi AA, Suputra G, Widyadharma IPE. High serum lead levels increase the incidence of cognitive impairment of public fueling station operators. Open Access Maced J Med Sci. 2019;7(4):599-602. doi:10.3889/OAMJMS.2019.127

24. Jain RB. Lead and kidney: concentrations, variabilities, and associations across the various stages of glomerular function. J Trace Elem Med Biol. 2019;54:36-43. doi:10.1016/j.jtemb.2019.03.007

25. da Cunha Martins A, Mazzaron Barcelos GR, Jacob Ferreira ALB. Effects of lead exposure and genetic polymorphisms on ALAD and GPx activities in Brazilian battery workers. J Toxicol Env Heal A. 2015;78(15):1073-1081. doi:10.1080/15287394.2015.1055527

26. La-llave-león O, Méndez-Hernández EM, Castellanos-Juárez FX, et al. Association between blood lead levels and delta-aminolevulinic acid dehydratase in pregnant women. Int J Env Res Public Health. 2017;14(4):432. doi:10.3390/ijerph14040432

27. Flora G, Gupta D, Tiwari A. Toxicity of lead: a review with recent updates. Interdiscip Toxicol. 2012;5(2):47-58. doi:10.2478/v10102-012-0009-2

28. Dongre NN, Suryakar AN, Patil AJ, Ambekar JG, Rathi DB. Biochemical effects of lead exposure on systolic \& diastolic blood pressure, heme biosynthesis and hematological parameters in automobile workers of North Karnataka (India). Indian J Clin Biochem. 2011;26(4):400-406. doi:10.1007/s12291-011-0159-6

29. Corradi M, Goldoni M, Sabbadini F, Mutti A. [Acute Lead Poisoning: A Singular Case of Hemolytic Anemia andLead Colic]. Med Lav. 2011;102 (3):243-249. Italian. 


\section{Publish your work in this journal}

The Journal of Blood Medicine is an international, peer-reviewed, open access, online journal publishing laboratory, experimental and clinical aspects of all aspect pertaining to blood based medicine including but not limited to: Transfusion Medicine; Blood collection, Donor issues, Transmittable diseases, and Blood banking logistics; Immunohematology; Artificial and alternative blood based therapeutics; Hematology; Biotechnology/nanotechnology of blood related medicine; Legal aspects of blood medicine; Historical perspectives. The manuscript management system is completely online and includes a very quick and fair peer-review system. Visit http://www.dovepress.com/testimonials.php to read real quotes from published authors.

Submit your manuscript here: http://www.dovepress.com/journal-of-blood-medicine-journal 